\title{
RECREATIONAL APPROACH TO REALIZATION OF SOCIAL WORK PRINCIPLES
}

\section{Kostyuchenko O. V.}

\section{INTRODUCTION}

The complexity and conflicting development of social relationships in the Ukraine require the new integrated knowledge of the person's life in dynamic social area and needed means of social help for full realization of his/her abilities in any possible situations. The prioritized themes for analysis in social-liberal sciences are inconsistent social process and a specific individual who experiences this process in his/her daily life. The reactions on experience are not identical for each person and sometimes they cause the active concern of society. One of the forms of concern is a social help.

The National Association of Social Workers of USA developed the full description of the essence of social work. It is a professional activity for giving help to individuals, groups or societies, strengthening or restoration of their abilities for social life and providing favourable conditions for attaining these goals. In the context of our analysis we pay attention on the process of social work that is realized on the micro-level (among others such as meso-level and macro-level) of society development. The latter is based on the interactions and interrelationships between individual and society. The adaptive-development theory and practice of social work is a basis for our studies ${ }^{1}$.

The responsibility, skill, creativity of each professional in any sphere and in social work particularly not only provide the progress of society but become the guarantee of the favourable existence of a person, and protect him/her from the loss of job, stresses and poverty. An issue of searching of the ways for success, contented, decent, and prosperous life is relevant in any sphere and particularly in area of social security, benefits, help for different categories of population which are carried out through such functions as: organizational (arrangement of particular

\footnotetext{
1 Лукашевич М.П., Мигович І.І. Теорія і методи соціальної роботи. 2-е вид., доп. І випр. К.: МАУП, 2003. $168 \mathrm{c}$.
} 
activities, influence on the content of leisure, assistance in an employment, career guidance, adaptation and so on); prognostic (programming and forecasting of social development process of district and household, the activities of the specific and various institutions, which participate in social formation of person); preventive-prophylactic and social-therapeutic (foresight and prevention, and overcoming the negative impact in social-legal, juridical and psychological areas and so on); organizational-communicative (recruiting of assistants-volunteers and people of the district for social work and recreation, business and personal contacts, storage of information and arrangement of contacts between various social institutions in the work with clients); protectivesafeguarding (the application of set of legal norms for protection of client's rights and interests, the assistance in enforcing of the governmental coercive measures and invoking legal responsibility of the persons who intentionally and unintentionally commit unlawful acts).

The applied goal of this publication is to illuminate the ways of recreational approach for effective addressing of the problem solution in professional activities of social worker and teacher. The modern living conditions and professional activities are characterized by heavy a mental stress, a chronic overstrain, a heightened level of anxiety, emotional and informational stresses, and by other etiological factors. Its actions cause in most cases overstrain and asthenia of adaptation mechanism, exhaustion of body functional reserves, reducing the ability to work that require more carefully weighted demands for development and implementation of methods and techniques, resources and conditions for renewal and restoration of human adaptive mechanisms. Therefore the psychotechnologies are developed that assist in better understanding of personal inner light, controlling of one's own desires and actions, developing and making the most of the essential potential.

The psychological backup of social pedagogue's and worker's professional activities will contribute to: 1) performance of professional plans and aspirations; 2) discovering one's own and his/her client's abilities and reserves; 3) highlighting the aspects of vitality - his/her motivational and operational spheres; 4) clarifying criteria, levels, periods, factors that support or impede a worker or a client elucidating the stages toward resolution of the on-going problem; 5) studying the personal past 
and present experience, clarifying the future; 6) correlation between personal competence and inconsistent challenges of society and so on.

This publication updates the issue of developing the social pedagogues and workers professional competence. The article primarily directs to elucidating the theoretical, methodological and psychological aspects of their professional activities in context of holistic recreational approach with the purpose of personality restoration in physical, psychological (intellectual and emotional), professional, cultural, spiritual aspects. The main task is to point out at a wide range of opportunities for social workers in sphere of their recreationally directed professional activities that brings to fullness the creative and personal potentials when such opportunities are continually expanded. That expansion of opportunities increases the level of communicative skills and creativity, predestines the multifaceted influence of the experience on the professional skills and the creative development of a person, efficiently and inventively discovers possibilities and abilities which are needed in order to gain and practice required knowledge, skills, and experience for analysis of specific business, social-psychological situations and events.

\section{The recreative and adaptative component of social work}

It is important to understand that the socialization occurs without particular deviations if conditions created by society ensure effective socialization and/or a person's capability meets a norm.

Such modern models of socialization as psychoanalytic or "Personal control" (S. Freud), "Role training" (T. Parsons), "Social learning" (G. Dolat, B. Skinner, etc.), "Interpersonal communication" (C. Coolley, G. Mead, etc.), "Cognitive" (J. Piaget, A. Maslow, etc.), and "Evolutionary" (E. Erikson) consider socialization as a process of human interaction with the surrounding community.

These are a process of integrating of an individual into a social system and adapting him to new social conditions and a process of becoming a personality as a social being, whereby various relationships of the individual with society are established., orientation, values and norms are developed, personality traits evolve, activity and integrity of the person are formed, social experience is accumulated, accumulated by humanity for the entire period of its development. The orientation, values, and norms are learnt. Personal characteristics are developed, activity and integrity of the 
personality are formed, and social experience accumulated by humanity for the entire period of its development is acquired.

A moment of dynamic equilibrium, harmonization of norms and traditions of the environment and human behavior occurs at a certain level of socialization of the interaction of personality with the environment. The achieved level of socialization allows an individual to operate naturally in a changed environment relying on a new higher level of his/her adaptive capacity. This shows the dialectic interaction of the functions of socialization and adaptation. However, when the social conditions of socialization or the physical, mental or spiritual health of a person deviate from the necessary level for an effective socialization socialization occurs with complications. So, a person and even some social groups are involved into difficult life situations and require social help from the state, its institutes or other subjects of a specific activity which is called social work.

An individual requires professional social help in order to adapt to crisis situation in life and overcoming the stress. Social work allowes the necessary social correction of the deviation (or support) of the individual adaptive mechanism of a client and, if it is necessary, facilitating adaptation of the real life situation.

Regarding this issue the following terms are used in the scientific literature: "social policy", "social work", "social insurance", "social services", "social support" and "social assistance" (S. Belicheva, V. Bocharova, S. Hrihoreva, I. Zimnya, A. Kozlova, V. Kolkova, P. Pavlenok, A. Banova, A. Sorvina, E. Smirnova, L. Topchiy, M. Firsova, E. Holostova, B. Shapiro, T. Selyaha, N. Shmilova, N. Shchukina, V. Yarska etc.). The Ukrainian scholars (O. Horpinich, N. Ivanova, V. Kolyadenko, A. Silenko etc.) focus on applied aspects of social work.

As used in this study the interpretation of social work is accepted as "a type of social activity aimed at the harmonization of personal and social relations by means of care assistance to individuals, groups of people and communities experiencing difficulties in social functioning by protection, support, correction and rehabilitation, and changing or reforming of certain elements of the social system", , which is social assistance (L. Stefan, I. Prokopenko, V. Lozova) in the relations and interaction of society,

\footnotetext{
${ }^{2}$ Социальная работа / под ред. В.И. Курбатова. 2-е изд. Рн/Д.: Феникс, 2003. С. 7.
} 
aimed at optimizing of the existence of the individual, the technology of the formation, implementation and rehabilitation of a human vital forces.

Thus, the Austrian Academy of Social Work suggests considering social work as a specific form of help to people from a society in meeting their social needs and solving conflict situations caused by individual or social reasons. One of the important organizational principles of social work is the inducement of a person to a conscious, interested expression of activity in the realization of his/her own energy, abilities, moral and volitional potential for the achievement of a certain goal. It is understood that the source of the motive force in some sort of activity is not the interests and needs of a person by itself and the level of their satisfaction.

The integrity and comprehensiveness of solution of social problems is arranged by complexity in social work when internal and external conditions, factors, states in interconnection and mutual interactions are taken into account. Social work has a complex integrated nature realizing its creative potential through numerous functions. The main functions are epistemological, organizational and educational, regulatory and preventive, information and communication, socio-integration, analytical and predictive.

The complex-oriented approach (humanistic, existential, psychodynamic, systemic-ecological, role-based, social-pedagogical, cognitive theory) to social work is based on a recreational basis by optimizing of the client's own efforts to use his personal and social resources in influence to the situation and maintain balance between the client and the environment.

According to the declared subject, we will focus on the recreational approach as a synthesis of different theories and practices. The problems that are devoted to the theory and practice of recreation are discussed quite actively in current science. As for the definitions of recreation, the problem lies not so much in the existence of different approaches to the interpretation of this concept as in the identification of the last with the other concepts - "rest", "entertainment", "leisure", "restoration of forces", "recovery", etc. ${ }^{3}$. We read at the Latin-Ukrainian dictionary ${ }^{4}$ re-creare, creo, avi, atum - 1) reproduce, recover, renew (aliquid); 2) remake, convert (vitam); 3) restore, support, refresh (vires)// strengthen, cheer up (afflictum

\footnotetext{
${ }^{3}$ Кант И. Соч. в 6 томах. Т.6. М., 1966. 365 с.;

Кірсанов В.В. Основні напрями дослідження рекреації. Вісник книжкової палати. 2004. № 10. С. $19-23$.

4 Латинсько-український словник: 10 тисяч найуживаніших латинських слів 3 максимальним відтворенням їхніх значень українською мовою. Київ : Українські пропілеї, 1998. С. 548.
} 
animum; mentem); 4) se, aбo pass. recreari - retreat (ex or a timere); to recover (e morbo); revive, regain strength (res publica recreatur); to rest, recover (litteris sustentari et recreari). Therefore, the definition of the recreation is rather vague. The ability to occure at any time, has an active character, is based on a voluntary and self-basis, and aimed at healing, may have a cognitive nature and be a means of self-affirmation are characterised as the recreation.

The recreation is compensation not only for overloads, but also for underloading. It should be noted that the compensative nature of recreational activity gives an opportunity to comprehend deeper and further grasp its connection with creativity and self-realization.

This is not just about compensation in the physical, mental, intellectual, but also about re-creativity (re-creare) in the large sense of the word, which finds its manifestation in cultural, spiritual, existential activity, in the realization of abilities, aspirations of the person, its the need for self-expression (revealing essential forces), self-improvement, creative development, etc.

Assume that the recreation is a process and means of recreation of a person in physical, mental, cultural and spiritual aspects then the psychological and pedagogical supplying of the recreation can be considered within each of these aspects. At the same time, the fundamental is reproduction, recreation, and not just restoration, because recreativeness is connected also with the realization of potentials, the essential forces of the individual - desire of the individual to reproduce him to the level of the ideal "I-image".

Special attention should be paid in social work to the processes of creativity and the disclosure of creative potential of the individual as the most important condition for its self-realization when considering various psychological and pedagogical fields of study of recreation. Its selfrealization is especially important in the context of the necessity to reorient of a person from the passive-consumer to the creative activities. The creative activity is connected with meaningful components of human life and is a necessary condition for finding meaning of life.

At present, the actualization of social work is due to such considerable interferences as today's development and the complication of the phenomenal phenomenon of the world. One of the indicators of adaptation to it is the state of harmony which from the subjective prospect is the 
perception and experience of well-being in its various aspects ${ }^{5}$ : spiritual (feeling of involvement in the spiritual culture of society, awareness of the possibility of being involved in the wealth of spiritual culture), social (the satisfaction of the individual with his/her own social status and the actual state of society to which the person attributes to himself, satisfaction with interpersonal connections and status in the microsocial environment); the salutary (physical) (good physical well-being, physical comfort, a sense of health, satisfaction with physical tone) and the most relevant for our research psychological (mental comfort associated with the coherence of mental processes and functions, a sense of integrity, internal balance. Its cognitive component implies the integrity, relative inconsistency of subjectivity the world views, the understanding of the current situation of life, and the emotional component - an experience that combines feelings due to the success of the subject in a particular areas of activity) ${ }^{6}$.

The statute of the World Health Organization (WHO) states "Health is not only the absence of a disease or physical defects, but full physical, mental and social well-being"7. This notion of health indicates a close psychosomatic connection of a person with many internal and external factors. Life-sustaining activity as a component of a living system is provided at different, but interrelated levels of functioning.

It can be distinguished conditionally three very specific levels of consideration: biological, psychological and social. Human health has features of manifestation with each of them. Regarding the healing, Recreational issues can be interpreted from the perspective of this definition of health.

The concept of psychological health that can sometimes get close to the concept of spiritual or mental health of a person is defined as a higher level of demonstration of intelligence, feelings, self-regulation ${ }^{8}$. Mental health is a state of mental well-being, which is characterized by the absence of painful mental manifestations and provides for the regulation of behavior that is adequate to the environment. This concept includes medical and psychological aspects, social, group norms and values that regulate the spiritual life of a person.

\footnotetext{
${ }^{5}$ Ахмедов Т.Н., Жидко М.Е. Психотерапия в особых состояниях сознания: История, теория, практика. Харьков: Фолио, М.: АСТ, 2000. 768 с.

6 Психологічне забезпечення психічного і фізичного здоров'я / За заг. ред. М.С. Корольчука. К.: ШКОС, 2002. 296 с.

${ }^{7}$ Никифоров Г.С. Психология здоровья. СПб: Речь, 2002. 256 с.

${ }^{8}$ Моляко В.О. Психологічна теорія творчості. Наукові записки Інституту психології ім. Г.С. Костюка АПН Украӥни. К., Нора-Прінт, 2002. Вип. 22. 350 с.
} 
Perception which manifests itself in the adequacy of subjective images that reflect objects of reality and the nature of reactions to external stimulating substances plays a crucial role in a set of criteria that determine the norm of mental health such as the significance of life events; the level of maturity corresponding to the age, emotional-volitional, and cognitive sphere of the individual; adequacy in microsocial relations; the ability to self-regulate behavior, intelligent planning of life goals, and activity in its achievement.

Social health is defined as an adequate perception of social reality, interest in the surroundings, adaptation to the physical and social environment, focus on a socially useful business, a culture of consumption, altruism, empathy, responsibility to others, selflessness, and behavioral democracy.

The question of the criteria for assessing the mental health problem is key. The most often separated criteria for mental health are mental balance, which can characterize the features of the functioning of the mental sphere of man on various sides - cognitive, emotional, volitional; the ability to logically process information; critical thinking; creativity; discipline of reason, which certainly can not be achieved without maximum approximation of subjective images to objects of reality that they reflect (the adequacy of mental reflection); adequate perception of oneself and the world, etc. ${ }^{9}$.

The adaptability to objective conditions depends on the level of mental equilibrium (V. Myasishchev). The equilibrium of the person and the adequacy of his/her reactions to external influences are of a great importance in relation to the distinction between norm and pathology. The only mentally healthy (equable) person is a manifestation of comparatively persistent behavior and the adequacy of its external conditions and the high individual adaptability of an organism to the usual changes of the environment, the ability to maintain the usual comfortable feeling of selfawareness, morphofunctional preservation of organs and systems. This criterion is closely related to the other two - the adequacy of the organization of the psyche and its adaptive capabilities in which the perceptual components are activated ${ }^{10}$.

\footnotetext{
${ }^{9}$ Никифоров Г.С. Психология здоровья. СПб: Речь, 2002. 256 с.;

Розов В.І. Адаптивні антистресові психотехнології. К.: Кондор, 2005. 278 с.;

Сандомирский М.Е. Защита от стресса. Физиологически-ориентированный подход к решению психологических проблем (Метод РЕТРИ). М.: Из-во Института Психотерапии, 2001. 336 с.

${ }_{10}^{10}$ Мясищев В.Н. Психотерапевтическая энциклопедия. СПб.: Питер, 2000. С. 394-195.
} 
Developing a system view of adaptation and self-regulation, Y. Aleksandrovskii considers adaptability as the result of an integrated self-directed system consisting of subsystems. There are search, perception and processing of information; social psychological contacts; regulation of sleep and not sleep; emotional response; endocrine-humoral regulation which are in mutual compensation and form an individual adaptation barrier. "The presence of mechanisms of conscious self-regulation is essential in this system" $"$.

Thus, based on the analysis of the scientific literature, adaptation can be interpreted as a phenomenon that has three general aspects of consideration in the context of recreation ${ }^{12}$.

The first aspect focuses on the characteristics of the process of adaptation to the new environment. In this context, the systemic aspect of considering the adaptation process becomes important, where the environment and subject of the adaptation process are considered as multilevel systems. The problem of adaptation was studied in physiology at a specific scientific level (L. Abolin, P. Anokhin, V. Petrovsky, S. Kriagzhde, H. Selie, N. Yakovlev, etc.); psychology [B. Ananiev, B. Asmolov, B. Benediktov, I. Boyko, L. Vygotsky, A. Rean, A. Petrovsky, P. Prosetsky, V. Semichenko, A. Maslow, etc.); pedagogy, theory and methodology of sports training (S. Voitsekhovsky, N. Volkov, V. Keller, P. Lesgaft, V. Platonov, etc.); Sociology and Culturology [A. Andreyeva, A. Bandura, V. Vasiliev, A. Georgievsky, I. Miloslavova, H. Tsaregorodtsev, B. Parigin, etc.).

The second aspect of the study of adaptation focuses on the balance of a subject and an environment in the integrated space of the "adaptation space". This balance allows us to study the various characteristics of the environment and the organism from the prospect their equilibrium that is very important for determining the nature of the specific problem of adaptation.

For instance, A. Heorgievsky emphasized the adaptation process as a certain form of the reflected interaction of the external and internal environment with a tendency to establish a dynamic equilibrium.

\footnotetext{
${ }^{11}$ Александровский Ю.А. Состояния психической дезадаптации и их компенсация. М.: Наука, 1976. 272 c.

${ }^{12}$ Костюченко О.В. Основні напрями психологічного дослідження адаптації та рекреації у контексті психічного здоров'я. Актуальні проблеми психологї. Т. 12. Вип. 10. Житомир: Вид-во ЖДУ ім. І. Франка, 2010. С. $154-161$.
} 
N. Melnikova notes the adaptation tends to a certain balance, starting with the imbalance between the two systems and coordination between them. As a result, there may be changes in both of them.

The focus on new features of the system "organism-environment" refers to the third aspect of the phenomenon of adaptation. This moment is important, given the fact that the result of the adaptation process can not be studied only as a fact of life activity, but also it is characterized by qualitative changes in the properties of the subject and the circumstance. B. Lomov considered adaptation as the interaction of "sub-system" and "megasystem" contradictions that exist both externally and internally ${ }^{13}$.

Another important issue for the studied problem is that the person in the adaptation process is considered not only as an object of influence from the side of the environment, but as an active system. This is a subject that seeks to change the environment, strives for self-assertion and self-realization, and in the process of adaptation acquires new cultural, social qualities, value orientations, knowledge, skills, forming their own perception of the world, etc. Thus, it becomes clear the meaning of the study, that the subject's purpose is his/her life goals.

Considering the role of creativity in adapting a person to a constantly changing world, V. Molyako proposes to take into account the "creativetransforming" function of consciousness, "the strategic organization of consciousness that allows regulate the content of the stream of consciousness. This allows finding specific systems in chaos design them and build, focusing also on objective indicators, set by all those requirements that exist in reality" $" 14$. These are strategies that allow you to organize the "chaos of thinking", find ways and means of ordering that will solve new tasks, complete the creative process by achieving balance through harmonization.

The image of the world which is formed in accordance with the giftedness of the individual is considered as its systematic formation which coordinates, regulates and stimulates creative activity. This is a peculiar measure of genetically and experimentally-conditioned human ability to adapt to life.

\footnotetext{
13 Ломов Б.Ф. Методологические и теоретические проблемы психологии. М.: Наука, 1984. 444 с.

14 Моляко В.А. Проблемы психологии творчества и разработка похода к изучению одаренности. Вопросы психологии. 1994. № 5. С. 86-95.
} 


\section{The recreational psych-technologies as tools of social work}

We note that certain psychological and pedagogical goals of social work are realized through appropriate recreational programs, measures and actions. At the same time different purposes require different programs, measures, actions for their realization. Since they often entail significant costs (financial, human, time, logistic burden, and so on) there is a need to create a jointed methodology for the development of complex, multipurpose programs that promote the achievement of several aims and in the same time save financial, human, time, logistical resources.

The general principle of solving this problem is the integration of two or more functional systems that have different goals into a single integrative polyfunctional (multi-purpose) system. We understand multifunctionality as an output principle of integrative model construction for theoretical justification and practical implementation of programs, events, psychologically oriented actions such as developing, formative, mobilizing, recreational, image creating etc. Thus, organization of events in a group promotes self-improvement based on the experience of group members, full self-expression, personality development and building the system of interpersonal relationship and world-view.

First of all, the development and implementation of multi-purpose programmes of various types suggest that they are to be designed at the level of theoretical integral models. The practical result of such modelling is that on the basis of a particular model of the programme becomes possible to arrange a variety of multi-purpose actions and events. Probably the most complex and the least developed questions are scientific and methodological justification of methods of organized recreational activities, and their professional application. It is necessary to take into account the fact that whatever methods we use we definitely leave an impression on the inner world of a person. Effective methods suggest not only the analysis of psychological and pedagogical essence of work with people of different ages but also a profound justification of methods and forms of their implementation.

The category of recreational technologies in social work in our edition is a complex integrative system that includes an ordered number of operations and actions. They define recreational purposes and provide meaning, informational, substantive and procedural aspects aimed at the restoration of the optimal psycho-emotional condition, learning, gaining 
skills and the formation of personal qualities that answer the pedagogical and psychological goals of training the target audience in the social work system. The structural components of such a system are: the purpose, content, process organization, participants of a process, technology specialist, system engineering complexes of psycho-pedagogical interaction, diagnostics of indicators before the implementation of psychotechnologies and the results of the recreational process.

Now we consider in more detail some of the structural components of the recreational program. Thus, the purpose of recreational psychotechnologies is the formation of a positive triple image "I-World-Others"; awareness of his/her own reserves and opportunities for creative selfrealization in this three ones. There is a short list of indications for the use of recreational technologies in order to fulfil the tasks. It can be following: lack of interest and indifference to the world around; reduction of working capacity; excessive emotionality; psycho-emotional stress; anxiety; the difficulties of emotional development; actual stress; decrease of emotional tonus; impulsive emotional reactions; low level of self-perception; lack of self-confidence; the need in communication; the need in communication with other people using the results of his/her labour; the development of creative ability; cognitive needs, striving for perceiving the world through its symbolization in a special form, the design of the world in the form of drawings, sculptures, tales, stories, choreography, singing etc.

For this purpose there is a need to create a harmonious space for recreational activities, based on the knowledge of exterior design and its particular impact. The tasks for achieving the goal can be following: overcoming uncertainty in communication; development of independence; formation of the ability to defend his/her position; awareness and disclosure of his/her own possibilities and abilities; promoting creative self-expression, and so on. These criteria for selecting a target audience are also signs that indicate the necessity to attend the specific events of recreational programme, and this is a kind of installation diagnostics. The age and sex of the group should be heterogeneous based on three main criteria: demographic (age, gender, education), problematic (symptoms, psychological diagnosis), personal (character, range of interests).

The organization and implementation of the recreational programme should be accomplished taking into consideration the inter-individual differences between subjects of the recreational activities, and in particular 
the following: age and personality development; age and education; psycho-physiological, behavioural and role differences between men and women (D. Kolesov, S. Kudinov, A. Anastasi, A. Koni), etc.

When we distinguish the known levels of psychotechnics ${ }^{15}$, we prefer the following: bioenergetic (regenerative nutrition, autophytic regulation, physical and motional activity), psycho-physiological (psycho-technology of adaptive bio control with biological feedback, progressive muscle relaxation, antistress relaxation, autogenic training, systematic desensitization; technique of breathing, body-oriented techniques, meditation), cognitive (neuro-linguistic programming (NLP); Design Human Engineering (DHE); cognitive therapy (A. Beck) and rationalemotive technique (A. Elisa), personal (psycho-synthesis of subpersonalities R. Assagioli; Gestalt technique for the awareness of needs; assertive) and relational (W. Glasser reality therapy, transactional analysis E. Berne, behavioural approach D. Volpe and A. Lazarus) etc. The emphasis is made on the fact that each of the recreational methods at any level makes a comprehensive impact on the physiological, emotional, intellectual, personal and social spheres of the individual, on the formation of his/her value orientations, moral, volitional and creative sphere bringing to fullness the adaptive and creative potentials. Therefore, to ascribe to any techniques or methods the level of reliability is rather arbitrary. It is caused by convenience of such classification that simplifies establishing the expediency of their use in the development of poly-functional recreational and educational programmes.

Now the effective psychological interactive forms and methods are in focus of our discussion. It is expedient to use them in social and psychological assistance to clients:

- psychogymnastics of cognitive activity is an effective method of optimizing the cognitive, affective and social-perceptual sphere of the individual. It focuses on the "language body" and spatial-temporal characteristic of communication. The method is aimed at solving the tasks of group psycho-correction: establishing a contact, removing the stress, tracking feedback, etc. ${ }^{16}$.

\footnotetext{
${ }^{15}$ Бурлачук Л.Ф., Кочарян А.С., Жидко М.Е. Психотерапия. Спб.: Питер, 2003. 480 с.;

Рудестам К. Групповая психотерапия. Психокорекционные группы: теория и практика. М.: Прогресс, 1990. 368 c.;

Ялом И. Теория и практика групповой психотерапии. СПб: Питер, 2000. 640 с.

16 Большаков В.Ю. Психотренинг. Социодинамика, упражнения, игры. СПб: Социальнопсихологический центр, 1996. 380 с.;
} 
- the use of graphic techniques, including drawing (Ricci, Cook, Preyer, Orshansky, Sally, Bechterev, Bakushinsky, Stern, Bühler, Arnheim, Muhina, Allan, Ponomarev, Furth, Dileo, Melik-Pashayev, Romenets, etc.) is a creative act that allows one to feel and understand oneself, freely express ones thoughts and feelings, be released from conflicts and anxieties, develop empathy, sensory-motor coordination;

- modern trends and methods of art therapy: landscaped is associated with the search and use of natural and man-made objects as the main material and means of creative activity; mask therapy is based on externalizing deep processes of a person into the mask. It helps to discover displaced and blocked emotions in order to release inter freedom; metaphorical ball is used to create successful communication; neurographics helps to express the experiences, conflicts, problems, positive goals using simple geometric figures and lines; beeswax therapy (it is a material that influence emotions) of anger, aggression, fear, anxiety, reticence; play dough therapy helps to reduce psycho-emotional stress; textile art therapy assists to find an outlet for inter feelings through the various pictures made on textile which contributes to the psychological changes related to ecology; therapeutic needle felting is the use of wool as a material for art and images; film therapy is a system of methods for working with reactions received by the client before, during and after watching a certain audio-visual products; photo-therapy is taking shots and/or reaction of a client on photographic images that is accompanied by discussion and various types of creative activities; food-art is usage the potential of food influence in order to meet basic human needs such as his/her relaxation and refreshing his/her inter resource;

- testing differs significantly from the usual psychological testing, first of all, that it should be taken as short as possible and be interesting to the participants. It is used to test participants' knowledge and skills, to identify learning motivation, to find out the effectiveness of certain exercises, methods, and activities in general. Of course, the uncomplicated test is an answering on multiple-choice questions by participants (e.g., "Non-existent animal", "Three desires", "Invisible hat", "Game room", "Finishing the image", "Questions about pictures", "A story based on pictures", "Pictogram", "Fantastic hypotheses", "Telling fairy tales", "Imagine that...", "If I...", etc.);

\footnotetext{
Технологии социально-психологических тренингов. Консорциума «Социальное здоровье России», 2001. 208 с.
} 
- bible-correction is a cultural practice of book selection for recreational purposes. It depends to a large extent on education, cultural needs of a person and also on his/her present emotional state;

- various forms of communication for stimulating creative-perceptual activities are used. For example: exercises for promoting acquaintance of participants in group interaction; psycho-technical games (L. Abramyan, A. Varga, I. Vygodskaya, A. Zakharov, A. Spivakovskaya, and al.), games: relaxation, communication, jokes, fantasy, developmental; related to kokology; situational and role based; business; role-playing; activitycommunicative, etc. The game purpose is to activate and release the abilities, to use the dormant human mental reserves, the expansion of the repertoire of self-perception and self-expression ${ }^{17}$;

- individual and group creative $\operatorname{tasks}^{18}$ provide almost unlimited possibilities for self-expression and self-realization as the results of creativity, facilitate the process of communication and establishing relationships with other significant people (relatives, peers, etc.);

- Aesthetic development is defined as "the development of the ability to experience various phenomena of reality as beautiful" ${ }^{19}$ by means of aesthetic and artistic (according to P. Jacobson) assessment as a human interaction with the "psycho-artistic" reality which contributes to the creation of a new, mental and spiritual reality ${ }^{20}$ by means of art in general. The main functions of aesthetic development $\operatorname{are}^{21}$ : cognitive, social, valueorientation, social-organizing, semiotic, communicative, hedonistic, aesthetic;

- Creative perception of the world reflected in the works of art and cultural-historical heritage is a complex, multilevel system that solves recreational tasks: the artistic organization of leisure, the integration of cognitive, entertaining and artistic creative function. Information-logical and

\footnotetext{
${ }^{17}$ Большаков В.Ю. Психотренинг. Социодинамика, упражнения, игры. СПб: Социальнопсихологический центр, 1996. 380 с.;

Вачков И.В. Основы группового тренинга. Психотехники. М.: Ось-89, 2001. 224 с.;

Корекційна робота психолога / упоряд. О. Главник. К.: К 66 Шкільний світ, 2002. 112 с.;

Технологии социально-психологических тренингов. М.: Редакционно-издательский центр Консорциума «Социальное здоровье России», 2001. 208 с.

${ }^{18}$ Рекреаційні аспекти активних творчих методів сенсорно-перцептивної активації для дітей підліткового та юнацького віку. Проблеми сучасної психології. Вип.19. Кам'янець-Подільський: Аксіома, 2013. C. 313-323.

${ }^{19}$ Психологический словарь / [под ред. В.П. Зинченко, Б.Г. Мещерякова). 2-е изд. М.: Астрель, 2004. C. 768 .

${ }^{20}$ Костюченко О.В. Художня перцепція в системі рекреації. Актуальні проблеми психологї. К: Фенікс, 2015. Т.ХІІ. Психологія творчості. Вип. 21. Ст. 174-184.

${ }^{21}$ Новиков А.М.. Методология художественной деятельности. М.: Сговес, 2008. 72 с.
} 
emotional-figurative effects are discovered in investigations of the museum educational potentials. The museum is a way for studying the world and it has a great cultural and recreational potentials as well as the ability to create conditions for the visitor's personal development, for his deepening in himself, self-identification, discovering his own place and role in the world.

One of the methods of attracting a museum visitor to active interaction is the game (game-journey, game-study, role-playing game). Such interaction with the museum environment that is organized in the form of a game, leads to a new, qualitative level of more full and deep perception of the documentary material. In this case the museum visitor receives not only the information load but also emotional unloading. In addition, he/she communicates with history not only on the intellectual level but also on the level of personal experience. When art museums is visited with the goal to immerse into an art that "reflects", "educates", "represents", and "calls" such interaction enriches spiritually the inner world of a person, gives aesthetic pleasure that is one of the ways for restoration of a person mental state. We hold that the essence of recovery mechanism is to supersede previous negative information that is felt in some form of fatigue, with positive information, that can cause positive feelings.

An important component of social work is an orientation of a client of a social assistance in area of enriched recreational environment, namely, providing favourable conditions that maximally contribute to the restoration of mental and physical capacities, and also successfully unload the psycho-emotional system in significant for the person activities. The main integral criteria of saturated recreational environment are the following:

1) Sensory stimuli: aesthetics and sensory richness of places for recreation; harmonization, structuring of the sensory environment (fine design of recreation);

2) Various types of activities: communicative activities serve as a way to organize the target audience - group work, collective discussion, decision-making, and discussion of the results; and also as a way of gaining knowledge; physical activities meet the needs in physical motions and development. They are an integral part of a healthy lifestyle and facilitate a person self-actualization;

3) Opportunities for cognitive activity of the individual: wide and free access to the necessary information is needed (consultations of 
specialists who teach special courses, etc.); diversity not only of content is required, but also in forms of presentation (lectures, seminars, instructions, discussions, etc.); saturation of communication with productive issues through skilful choice of meaningful goals;

4) Opportunities for the personal aesthetic activities should be aimed at satisfying the need for beauty (external, spiritual, relations);

5) Opportunities for bringing to fullness the creative abilities of individual should be offered in the variety of forms, content, and with orientation of cognitive activity. It is necessary to provide the possibility of making free choice of their interests and opportunities;

6) A degree of choice freedom of a person in various activities;

7) Optimal organization of activities;

8) The interaction of all participants in recreational activities.

Design and effective implementation of recreational programmes is one of the main means that creates a holistic "I-image" of the individual and his/her various components are taken into consideration. They are following: rational-cognitive (personal experience, theoretical notions); emotional-sensory (emotional response to the expression of his/her own self); sensory-perceptual (adequate perception of body signals, which are formed on the basis of "body schema" and supplemented by audible, visual and other signals); motivational (need to be a creative person, measure of responsibility, priority of psychological, mental, physical health in the individual system of values, readiness for creative activity in the system of well-being).

Transformation of "I-image" is determined by psychological, cultural, social, economic, family, educational relations. We cannot but agree with L. Vygotsky and H. Kostiuk, that the content of a person's image is influenced simultaneously by the cultural environment in which a person engages with others; the nature and content of the activity s/he does; relations that are established. In order to change the self-perception, raise the level of adequacy of the individual's self-esteem, bring into compliance pretensions of the individual with his capabilities, namely harmonize the components of "I-image", one can influence the personal orientation, the readiness of a person to behave in a certain manner, change the leading path, expand the area of the self-realization of the creativity and the world perception. 


\section{CONCLUSIONS}

Thus, we point out to the following important theoretical principles of our studies:

1) integrity, thoroughness in solving social problems are provided by holistic approach to social work taking into consideration internal and external conditions, factors, statuses in their interrelationship and mutual influence;

2) integral, all-embracing and orientated nature of social work reveals itself in bringing to fullness its creative potentials through the operation of numerous functions and particularly recreational function when personal efforts of a client are refreshed for using of his/her individual and social resources in order to influence the situation and to keep a balance between a client and living environment;

3) The theoretical foundations of adaptation and socialization in their interrelationship fulfil an important role in the theoretical justification of recreational mechanisms, means, and techniques of social work. The adaptation being a part of mechanism of socialization takes place as a total sum of adaptations to the diverse life situations when the social experience is accumulating the norms and values are mastered. Each step of the adaptation enriches the social experience and makes easier the further process of human adaptation. This is the essence of the adaptivedevelopment model of socialization that helps to open up the additional possibilities for correction of social work based goals and functions as supplementary mechanism of socialization;

4) The recreational approach itself that assists in realization of a social work is a synthesis of diverse theories and practices and it is directed to the restoration of a person (in physical, psychological, creative, cultural and spiritual aspects) who requires social assistance. The recreational approach is aimed toward carrying out of an important function of reflection; also it leads to realization of its prominent role in the processes of orientation in the surrounding reality, adaptation, and socialization as well as toward his/her real transformation;

5) Poly-functionality is the final goal of the integrative model construction as well as theoretical justification and practical fulfilment of the recreational programmes, measures, psychologically oriented actions (such as developing, formative, correcting, mobilizing, image creating and so on) on the basis of interpersonal distinctions of individuals who receive 
social assistance. Each of these recreational methods and tools comprehensively influences at any level of psycho-technology: physiological, emotional, intellectual, personal, and social spheres of personality. It supports the formation of his/her value orientations, moral, volitional, and creative sphere bringing to fullness the adaptive and creative potentials;

6) The fundamental principle of social work is a motivation of a person with awareness of what s/he is doing and willingness to use his/her own energy, abilities, moral, and volitional capacities for achieving specific purpose. Therefore we consider that the usage of this fundamental principle of social work will assist in attaining such recreational result as formed and enlarged optimistic-realistic world-view and adequate perception of the world by the subject of social work. Thus, such result is an important sign of his/her viability, worldly wisdom, and emotional resistance to adverse factors of everyday life, ability to adequately discern the real life situations and to effectively solve the issues associated with self-expression.

\section{SUMMARY}

The article theoretically analyses integral, all-embracing, and orientated nature of social work that reveals itself through the operation of numerous functions and particularly recreational function. This is possible by optimizing the personal efforts of a client in using of his/her individual and social resources in order to influence the situation and to keep a balance between a client and living environment. It focuses on explaining the possibilities to use the theoretical foundations of adaptation and socialization in their interrelationship particularly the adaptivedevelopment model of socialization. In order to justify theoretically the recreational mechanisms, means, and techniques of social work for correction of social work based goals and functions as supplementary mechanism of socialization.

This article pays attention on the recreational approach as a synthesis of diverse theories and practices, and particularly on the restoration of a person who requires social assistance in his/her different needs including an adaptation to the changing environment, and his/her real transformation and socialization. It demonstrates that poly-functionality is the final goal of constructing of the integrative models, theoretical justification, and 
practical fulfilment of the recreational programmes. The measures and psychologically oriented actions (such as developing, formative, correcting, mobilizing, image creating and so on) on the basis of interpersonal distinctions of individuals who receive social assistance refers to final goals as well.

The article mentions some recreational methods, tools that comprehensively influence physiological, emotional, intellectual, personal, and social spheres of personality; that support the formation of his/her value orientations, moral, volitional, creative sphere bringing to fullness the adaptive and creative potentials. The recreational result of the achieving the fundamental principle of social work is a formation, development of the optimistic-realistic world-view, and adequate perception of the world. Thus, such result is an important sign of his/her viability, worldly wisdom and emotional resistance to adverse factors of everyday reality, his/her ability to adequately discern the real life situations and to effectively solve the issues associated with self-expression.

\section{REFERENCES}

1. Александровский Ю.А. Состояния психической дезадаптации и их компенсация. М.: Наука, 1976. 272 с.

2. Ахмедов Т.Н., Жидко М.Е. Психотерапия в особых состояниях сознания: История, теория, практика. Харьков: Фолио, М.: ACT, 2000. $768 \mathrm{c}$.

3. Большаков В.Ю. Психотренинг. Социодинамика, упражнения, игры. СПб: Социально-психологический центр, 1996. 380 с.

4. Бурлачук Л.Ф., Кочарян А.С., Жидко М.Е. Психотерапия. Спб.: Питер, 2003. 480 с.

5. Вачков И.В. Основы группового тренинга. Психотехники. М.: Ось-89, 2001. 224 с.

6. Кант И. Соч. в 6 томах. Т.6. М.,1966. 365 с.

7. Кірсанов В.В. Основні напрями дослідження рекреації. Вісник книжкової палати. 2004. № 10. С. 19-23.

8. Коваль Л.Г., Звєрева І.Д., Хлєбік С.Р. Соціальна педагогіка. Сочіальна робота. К.: ІЗМН, 1997. 392 с.

9. Корекційна робота психолога / упоряд. О. Главник. К.: К 66 Шкільний світ, 2002. 112 с. 
10. Костюченко О.В. Основні напрями психологічного дослідження адаптації та рекреації у контексті психічного здоров'я. Актуальні проблеми психології. Т. 12. Вип. 10. Житомир: Вид-во ЖДУ ім. I Франка, 2010. С. 154-161.

11. Костюченко О.В. Художня перцепція в системі рекреації. Актуальні проблеми психології. К: Фенікс, 2015. Т. ХІІ. Психологія творчості. Вип. 21. С. 174-184.

12. Латинсько-український словник: 10 тисяч найуживаніших латинських слів 3 максимальним відтворенням їхніх значень українською мовою. К. : Українські пропілеї, 1998. С. 548.

13. Ломов Б.Ф. Методологические и теоретические проблемы психологии. М.: Наука, 1984. 444 с.

14. Лукашевич М.П., Мигович I.I. Теорія і методи соціальної роботи. 2-е вид., доп. і випр. К.: МАУП, 2003. 168 с.

15. Моляко В.А. Проблемы психологии творчества и разработка похода к изучению одаренности. Вопросы психологии. 1994. № 5. С. 86-95.

16. Моляко В.О. Психологічна теорія творчості. Наукові записки Інституту психології ім. Г.С. Костюка АПН України. К., Нора-Прінт, 2002. Вип. 22. 350 c.

17. Мясищев В.Н. Психотерапевтическая энциклопедия / Под. ред. Б.Д. Карвасарского. Изд. 2-е, доп. и перераб. СПб.: Питер, 2000. С. 394-195.

18. Никифоров Г.С. Психология здоровья. СПб: Речь, 2002. 256 с.

19. Новиков А.М. Методология художественной деятельности. М.: Єговес, 2008. 72 c.

20. Психологический словарь / [под ред. В.П. Зинченко, Б.Г. Мещерякова). 2-е изд. М.: Астрель, 2004. С. 768.

21. Психологічне забезпечення психічного і фізичного здоров'я / За заг. ред. М.С. Корольчука. К.: ШКОС, 2002. 296 с.

22. Рекреаційні аспекти активних творчих методів сенсорноперцептивної активації для дітей підліткового та юнацького віку. Проблеми сучасної психології. Вип.19. Кам'янець-Подільський: Аксіома, 2013. С. 313-323.

23. Розов В.І. Адаптивні антистресові психотехнології. К.: Кондор, 2005. 278 c. 
24. Рудестам К. Групповая психотерапия. Психокорекционные группы: теория и практика. М.: Прогресс, 1990. 368 с.

25. Сандомирский М.Е. Защита от стресса. Физиологическиориентированный подход к решению психологических проблем (Метод РЕТРИ). М: Из-во Института Психотерапии, 2001. 336 с.

26. Социальная работа / под ред. В.И. Курбатова. 2-е изд. Рн/Д.: Феникс, 2003. Ст. 7.

27. Технологии социально-психологических тренингов. М.: Редакционно-издательский центр Консорциума «Социальное здоровье России», 2001. 208 с.

28. Ялом И. Теория и практика групповой психотерапии. СПб: Питер, 2000. 640 c.

\section{Information about author:} Kostyuchenko O. V. Assistant Professor at the Department of Psychology of the Kyiv National University of Culture and Arts 